\title{
PEMUDA, DIASPORA DAN PENGGUNAAN MEDIA BARU DALAM GERAKAN SOSIAL SABANGMERAUKE
}

\author{
Syaifa Tania ${ }^{1}$, Massageng Widagdhaprasana ${ }^{2}$, Mashita Phitaloka Fandia \\ Purwaningtyas $^{3}$, Maulin Niam ${ }^{4}$ \\ ${ }^{1}$ Universitas Gadjah Mada, syaifa.tania@ugm.ac.id \\ ${ }^{2}$ Universitas Gadjah Mada, massageng@gmail.com \\ ${ }^{3}$ Universitas Gadjah Mada, mashita.p.f@ugm.ac.id \\ ${ }^{4}$ Universitas Gadjah Mada, maulinniam@gmail.com
}

\begin{abstract}
ABSTRAK
Kajian tentang diaspora saat ini menjadi semakin populer dikarenakan mulai diperhatikannya komunitas diaspora dalam peranannya untuk pembangunan negara atau bangsa di lokasi mereka berada. Di Indonesia, diaspora tidak hanya didominasi oleh generasi-generasi tua akan tetapi para komunitas pemuda diaspora sebagai generasi penerus bangsa mulai mengambil peranan dalam membangun Indonesia salah satunya di bidang pendidikan. SabangMerauke merupakan sebuah organisasi sosial yang dibentuk karena kegelisahan mereka terhadap pendidikan toleransi yang terjadi di Indonesia. SabangMerauke dibentuk oleh tiga pemuda Indonesia yang memiliki pengalaman hidup di lingkungan multikultural yang rawan akan konflik karena banyaknya perbedaan. Tumbuhnya gerakan sosial seperti SabangMerauke yang dipelopori oleh pemuda diaspora di Indonesia juga didukung dengan perkembangan media baru di Indonesia. Dukungan kemajuan teknologi informasi dan komunikasi berbasis internet terhadap media baru menjadikan media-media ini menjadi sumber informasi alternative dalam melakukan gerakan sosialnya di ruang-ruang maya. Penelitian ini bertujuan untuk mengeksplorasi hubungan antara pemuda, diaspora dan penggunaan media baru dalam gerakan sosial yang dilakukan oleh SabangMerauke. Metode penelitian kualitatif digunakan dalam penelitian ini untuk mendapatkan data yang medalam melalui studi pustaka, observasi online dan wawancara dengan salah satu pendiri SabangMerauke. SabangMerauke melakukan optimalisasi gerakannya dengan melakukan aktivitas offline dan online untuk menjaga kesinambungan gerakan sosialnya.
\end{abstract}

Kata Kunci : Pemuda, Diaspora, Media Baru, Gerakan Sosial, Toleransi

\section{ABSTRACT}

Nowadays, the diaspora studies popularly known globally as the rise of concern in diaspora community that have role on the development of nation based on where they lived. In Indonesia, the activism based on the diaspora are not only dominated by the older generation but also the young generation are starting the movements toward their role in developing nation particularly in the education field. SabangMerauke is one among many social organization that found based on their worryness toward the tolerance taught that happening in Indonesia. SabangMerauke was founded by three Indonesian young people who have similar concern in the development of tolerance taught in Indonesia. The rise of social activism such as SabangMerauke in Indonesia is also supported by the development of new media. The advancement of Information and Communication technology toward the new media enabled it as the alternative information source that helps the organization to do their social activism virtually. This research aims to explore the relationship between young people, diaspora and the use of new media in social activism. The qualitative methodologies 
are used to examining the object by conducting in-depth interviews, literature studies and online observation. english. This research founds that SabangMerauke is doing the offline and online activism in order to optimize their social activism to creating a sustainability for their activism.

\section{Keywords: Young people, Diaspora, New Media, Social Activism, Tolerance}

\section{PENDAHULUAN}

Beberapa tahun terakhir, terjadi peningkatan perhatian terhadap kajian tentang komunitas diaspora, terutama berkaitan dengan potensinya terhadap pembangunan di Negara atau bangsa dari mana mereka berasal.

Gagasan sederhana dari Diaspora Indonesia adalah untuk mempertemukan, menghubungkan kembali orang-orang Indonesia yang tinggal jauh dari kampung halaman. Dalam hal ini kehadiran media baru sebagai teknologi informasi dan komunikasi mutakhir menjadi katalis bagi tumbuhnya jaringan Diaspora Indonesia secara cepat. Saat ini, komunitas Diaspora Indonesia tidak hanya di dominasi oleh orang-orang tua saja akan tetapi kelompok pemuda baik yang tinggal di dalam maupun luar negeri, menyimpan potensi yang tak kalah pentingnya bagi perubahan positif bangsa Indonesia.

Media baru, teknologi informasi dan komunikasi berbasis internet, memberikan peluang bagi pemuda untuk berekspresi dan berinovasi dalam rangka mengambil peran dalam kehidupan sosial, politik, maupun budaya di lingkup lokal maupun global. Pengguna internet di Indonesia mengalami lonjakan yang luar biasa, dari hanya sekitar 2 juta di awal dekade 2000 meningkat menjadi lebih dari 143 juta jiwa pengguna di tahun 2017 (APJII, 2018). Jumlah itu meningkat menjadi 73 juta pada tahun berikutnya. Fakta menarik lainnya adalah pengguna social media (seperti Facebook, Twitter, Kaskus) menjadikan Indonesia termasuk 3 besar negara paling berisik di dunia. Pesatnya peningkatan jumlah pengguna internet di Indonesia seiring dengan meningkatnya pertumbuhan ekonomi dan membanjirnya mobile-phone di pasaran(APJII, 2018). Fenomena ini menjadi perhatian global dengan beberapa alasan. Pertama, dari segi ekonomi, besarnya jumlah netizen merupakan segmen pasar global yang sangat potensial. Bahkan Lowy Institute for International Policy menyebut bahwa orang Indonesia adalah konsumer paling percaya diri di dunia (Sharpe, 2014). Kedua, dari segi teknologi Indonesia memiliki infrastruktur jaringan telekomunikasi yang bisa dikatakan tertinggal jauh aka tetapi ternyata penggunanya sangat aktif dan kreatif dalam meramaikan jagad virtual. Ketiga, dari segi sosial budaya, besarnya jumlah netizen (pengguna internet) di Indonesia tak jarang membuat 'kicauan' mereka jadi trending topic di dunia virtual. Hal itu 'memaksa' netizen secara global untuk sekadar melirik apa yang sedang terjadi di Indonesia. Beberapa inovasi gerakan sosial dalam dunia online yang berdampak gerakan dan perubahan nyata di dunia offline justru lahir dari kreativitas netizen Indonesia. Hal ini mungkin tidak pernah terpikirkan sebelumnya oleh para pencipta aplikasi social media di Negara asalnya. Harus diakui bahwa belum banyak sumber daya manusia Indonesia yang mampu menciptakan platform komunikasi berbasis digital yang mendunia, tetapi dalam hal kreativitas dan inovasi penggunaan teknologi media baru netizen Indonesia tidak bisa dipandang sebelah mata.

Fenomena diaspora yang terjadi secara global dan konsep tentang identitas pemuda yang terbentuk dalam konteks diaspora pemuda merupakan konsep yang tak mudah untuk diuraikan. Sementara konsep yang terakhir merujuk pada maraknya penggunaan media baru, teknologi informasi dan komunikasi berbasis internet, sebagai alat menggalang gerakan sosial.

Tulisan ini bertujuan mengekplorasi hubungan antara ketiganya yaitu pemuda, 
diaspora dan penggunaan media baru dalam gerakan sosial. Bagaimana pengalaman diaspora yang dimiliki oleh alumni Pengajar Muda (dengan karakter pemuda yang pernah hidup di luar negeri, memiliki jejaring pertemanan internasional) yang memilih jadi pengajar sekolah dasar dan tinggal di daerah yang jauh dari perkotaan, minim fasilitas, dengan nilai-nilai budaya lokal yang kental selama setahun program. Pengalaman tersebut membuat mereka melihat realitas hubungan antarbudaya dan antaragama yang terjadi di masyarakat akar rumput. Selain itu pemuda diaspora juga merupakan generasi digital native, mereka lahir dan bertumbuh kembang di era teknologi internet yang serba digital dan terkoneksi. Sebagai pemuda generasi digital mereka menciptakan pola interaksi sosial termediasi teknologi yang disebut sebagai budaya digital. Kombinasi pengalaman diaspora dan budaya digital yang dimiliki, mereka berinisiatif melakukan gerakan sosial dalam terkait isu pendidikan toleransi di Indonesia.

\section{KAJIAN LITERATUR}

Pemuda Diaspora: Aktivisme Online dan Tumbuhnya Semangat Sukarela

'Pemuda' dan 'diaspora' adalah suatu konsep yang identik dengan sebuah perjalanan, melibatkan proses perpindahan atau melintasi batas ruang dan waktu, dan reorientasi kerangka pemahaman kita tentang ke'kini'an dan ke'di sini'an diri. Secara psikologis, pemuda adalah fase krusial atau anak muda sekarang mungkin menyebutnya 'masa-masa galau', dalam perkembangan hidup manusia. Sebuah fase peralihan dari identitas kanak-kanak yang masih bergantung pada orang lain menuju identitas diri sebagai pribadi dewasa yang mandiri. Identitas yang terbentuk, atau dibentuk, inilah yang kemudian menentukan peran individu dalam konteks sosial dan budaya.

Di sisi lain, konsep diaspora tak bisa lepas dari fenomena perpindahan manusia dari satu tempat ke tempat lain atau merasakan budaya satu dengan budaya lain. Fenomena migrasi (perpindahan) manusia sudah terjadi sejak berabad-abad lalu. Istilah diaspora berasal dari bahasa Yunani kuno yang terdiri dari kata dia (di antara, melalui, lintas) dan speiro (menyebar). Secara umum diaspora berarti populasi yang tersebar di berbagai wilayah dengan kesamaan asal dari wilayah geografis yang lebih sempit. Para ilmuwan sosial mendefinisikan diaspora secara berbeda sesuai dengan fokus dari disiplin ilmu masing-masing yang menyebabkan ambiguitas makna. Safran (1991) misalnya menekankan 3 gagasan utama dalam mendefinisikan diaspora yaitu 'identitas bersama' atau kesadaran kolektif atas asal usul baik berdasarkan suku, sosial budaya, Negara, agama dan lain sebagainya; keterpisahan (baik terpaksa maupun sukarela) dari kampung halaman yang berimplikasi pada adanya harapan atau komitmen untuk suatu saat kembali; dan kualitas hubungan budaya dengan komunitas diaspora dalam masyarakat di mana mereka tinggal. Dilihat dari lingkup wilayah migrasi, dikenal dua jenis diaspora yaitu transnasionalisme yaitu diaspora yang melibatkan minimal dua wilayah Negara dan diaspora lokal/internal yaitu diaspora yang terjadi karena perpindahan antarwilayah dalam satu Negara.

Konsep diaspora berkembang seiring dengan konteks sejarah, sosial budaya, dan ekonomi politik yang melatari aktivitas migrasi penduduk di berbagai belahan dunia. Secara umum, diaspora bisa diklasifikasikan menjadi 5 tipe (Cohen, 2008), yaitu:

1) diaspora korban/pengungsi, perpindahan yang terjadi karena adanya konflik, perang, atau bencana di daerah asal.

2) diaspora imperial/kolonial, perpindahan yang terjadi karena ekspansi wilayah jajahan.

3) diaspora pekerja/jasa, jenis diaspora yang terjadi pada keturunan pekerja paksa akibat penjahahan. Biasanya terjadi pada masyarakat poskolonial. 
Sebagai contoh komunitas suku Jawa di Negara Suriname.

4) diaspora dagang/bisnis/profesional, perpindahan yang terjadi karena aktivitas perdagangan, bisnis atau profesi.

5) diaspora deterritorial, diaspora yang terjadi tanpa harus melibatkan perpindahan lintas territorial (wilayah) secara fisik. Identitas yang terbentuk dari tipe diaspora deterritorial lebih pada aspek ideologi atau budaya.

Revolusi teknologi, terutama teknologi komunikasi dan informasi, di era globalisasi telah menghapus batas-batas ruang dan jarak geografis sehingga memudahkan komunitas diaspora untuk menjaga hubungan dengan sesama diaspora maupun dengan 'kampung halaman'. Hubungan diaspora, baik dengan sesama diaspora maupun dengan kampung halaman, yang terfasilitasi teknologi digital menjadi makin intensif. Berkat teknologi komunikasi dan informasi, titik-titik (dalam hal ini individu maupun komunitas) diaspora tersambung dan terungkap potensi-potensi yang selama ini tersembunyi. Bahwa generasi keturunan diaspora ternyata banyak yang menjadi orang sukses dan menduduki posisi strategis dalam bidang ilmu pengetahuan, sosial, budaya, olahraga, bahkan politik dan ekonomi di Negara masing-masing.

Kajian tentang diaspora pun semakin berkembang dan bergeser pada potensi komunitas diaspora dalam memberikan kontribusi bagi pembangunan/kemajuan Negara asalnya. Pemerintah Kanada secara formal membuat sebuah proyek pengembangan potensi trans-lokal diaspora dalam konteks pembangunan baik di Kanada maupun di Negara asal. Ada tiga konsep utama yang menjadi atribut dalam upaya mengoptimalkan peran diaspora bagi pembangunan yaitu: 1) community (Komunitas), variasi identitas dan hibriditas budaya yang terbentuk, pengaturan tentang batas, dan tingkat orientasi tentang bangsa asal (secara real atau yang dibayangkan) sebagai acuan nilai, identitas, dan loyalitas; 2) trans-locality (Perubahan), pola persebaran, dan hubungan sosial yang terjadi di dalam maupun ke luar batas Negara; 3) network (Jaringan), jenis dan tingkat kelembagaan yang membentuk jejaring interaksi, komunikasi, dan aksi di antara komunitas diaspora sebagai sebuah organisasi sosial (Busumtwi-Sam \& Anderson, 2010).

Fenomena yang terjadi di Indonesia, khususnya Jakarta sebagai simbol kota metropolitan. Dalam kurun waktu yang relatif bersamaan sebagian masyarakat ramai menggalang gerakan sosial untuk menuntut keadilan sosial, pemenuhan hak asasi manusia, kesetaraan hak warga negara, kebebasan berekspresi. Sementara di lain pihak, sekelompok masyarakat dengan mengatasnamakan agama menebar teror dan menyerang kelompok agama lain. Di satu sisi perilaku beragama Islam semakin marak, tayangan keagamaan di televisi makin populer tetapi di sisi yang lain Jemaah Ahmadiyah dilarang dan diserang oleh sesama kaum muslim.

Gerakan sosial terjadi di berbagai belahan dunia, dengan alasan yang beragam tetapi yang jelas, menyuarakan protes tentang bagaimana masyarakat diperlakukan secara tidak adil oleh pemerintah atau system yang sedang berkuasa (Clark, 2012). Gerakan sosial sudah menjadi fenomena dalam skala global tidak hanya ketika diberitakan oleh media massa tetapi juga didokumentasikan dalam bentuk foto, film, bahkan disebarkan secara viral ke seluruh dunia melalui internet. Bagaimanapun, gerakan sosial selalu bersifat politis. Gerakan sosial lebih menekankan kepada dimensi praktis daripada formal. Melalui aksi massa, sebuah gerakan mampu menciptakan tekanan kepada penguasa untuk memengaruhi kebijakan pemerintah (Aday et al., 2010).

Perkembangan teknologi informasi dan komunikasi memberi peluang terjadinya gerakan sosial dengan cara-cara baru di era informasi sekarang ini. Perangkat 
media baru, teknologi komunikasi dan informasi berbasis internet, menawarkan infrastruktur komunikasi yang cepat, murah, dan lintas batas geografis sehingga mampu mengubah ketidakpuasan sosial menjadi aksi massa dalam hitungan menit atau jam saja, seperti yang terjadi ketika ada isu pengepungan gedung KPK oleh aparat polisi atau pengumpulan uang dalam bentuk koin untuk membayar denda yang dijatuhkan pengadilan kepada Prita, seorang ibu rumah tangga yang dituduh melakukan pencemaran nama baik sebuah rumah sakit internasional karena menuliskan pengalaman buruk yang dialami melalui internet. Dalam kondisi darurat seperti bencana alam, media baru terbukti berperan penting baik sebagai sumber informasi alternatif maupun sebagai alat pengorganisiran bantuan sebagaimana yang dilakukan oleh @ JalinMerapi (Nugroho \& Syarief, 2012). Gerakan Koin untuk Prita dan Cicak vs Buaya seringkali dikutip sebagai contoh kasus keberhasilan aktivisme online. Meskipun menurut Merlyna Lim, hampir seluruh gerakan sosial yang lahir setelahnya gagal meniru keberhasilan kedua kasus tersebut (Lim, 2013).

Terlepas dari besaran area maupun dampak yang dihasilkan, penggunaan media baru dalam strategi gerakan sosial terus bermunculan dalam berbagai isu. Banyak gerakan sosial di berbagai isu publik yang diinisiasi dan dikelola melalui media baru oleh netizen di Indonesia. Beberapa di antaranya seperti SabangMerauke, Coin A Chance, Blood for Life, Akademi Berbagi, dan Indonesia Berkebun adalah gerakan sosial yang menggunakan media baru, khususnya social media sebagai platform utama dalam memasarkan gagasan. Berdasarkan pengalaman gerakan-gerakan tersebut, social media menjadi pemicu bagi beberapa perubahan di kehidupan nyata atau kadang disebut sebagai realitas offline.

Peran social media, bagi generasi muda Indonesia, bahkan lebih besar dibandingkan media massa pada umumnya. Berdasarkan laporan APJII, profil pengguna internet di Indonesia pada 2014 pengguna internet didominasi oleh penduduk usia muda (18-35 tahun) sebanyak $82,8 \%$ dengan pengguna internet tertinggi pada kelompok usia 1825 tahun. Penggunaan internet di Indonesia juga lebih banyak bersifat sosial, $87,8 \%$ untuk jejaring sosial, $69 \%$ mencari informasi/browsing, instant messaging $60 \%$ dan mencari berita terkini 60\% (APJII, 2015).

Salah satu ciri khas dari gerakan sosial adalah keterlibatan tenaga-tenaga yang bekerja secara sukarela atau biasa disebut relawan. Istilah relawan merujuk pada seseorang yang berinisiatif untuk menyumbangkan waktu, tenaga, dan potensi yang dimilikinya sebagai bentuk tanggung jawab diri maupun sosial kepada lembaga/masyarakat tanpa secara sukarela/tidak untuk mencari keuntungan finansial. Ada beberapa alasan mengapa gerakan sosial melibatkan relawan antara lain mengatasi keterbatasan sumber daya manusia dan keterbatasan sumber daya manusia, sebagai memperluas jangkauan visi, misi, dan dampak dari gerakan sosial. Selain itu pelibatan relawan juga berfungsi sebagai ajang kaderisasi sekaligus pendidikan publik atas isu yang diusung.

Di sisi lain, pelibatan pemuda dalam gerakan sosial, terutama melalui social media, juga bermanfaat bagi kesehatan perkembangan pemuda. Blum menyebutkan ada 4 indikator kesehatan perkembangan pemuda yang dapat dicapai melalui keterlibatan dalam gerakan sosial: 1) kompetensi di berbagai bidang kehidupan dan keterampilan interpersonal; 2) koneksi dengan berbagai pihak melalui hubungan bersifat persahabatan; 3) pembentukan karakter melalui penanaman nilai-nilai positif seperti tanggung jawab, kepedulian sosial, dan jiwa pengabdian; 4) rasa percaya diri yang akan menumbuhkan semangat/harapan dalam menetapkan tujuan dan keyakinan atas keberhasilan di masa depan (Lombardo, Zakus, \& Skinner, 2002). 
Salah satu lembaga yang fokus menggarap potensi relawan adalah Masyarakat Relawan Indonesia (MRI). Selama kiprahnya, MRI telah terlibat dalam berbagai permasalahan kemanusiaan, seperti bencana alam, bencana sosial, gizi buruk, dan kegiatan advokasi masyarakat dalam memperoleh hak-haknya. Dari tahun 2005, relawan yang pernah beraktivitas bersama MRI mencapai lebih dari 41 ribu orang. Dari jumlah itu, 23 ribu orang diantaranya siap untuk membantu kapan saja dibutuhkan dan sudah terdaftar secara resmi dalam database MRI (MRI, 2019).

Teknologi informasi semakin sering digunakan untuk menciptakan cara baru dalam mengelola relawan seperti database online, diskusi online, dan social media banyak membantu organisasi untuk berhubungan, merekrut, dan melibatkan relawan dari berbagai wilayah demografis Vo (Speevak-Sladowski, Hientz, \& MacKenzie, 2013). Di Indonesia sendiri, fenomena relawan dalam gerakan sosial makin populer dengan adanya teknologi social media. Salah satunya adalah gerakan TurunTangan yang digagas oleh Anies Baswedan. Hingga kini relawan Turuntangan yang resmi terdaftar berjumlah 36,898 orang dengan mayoritas berasal dari anak muda. Fenomena relawan di Indonesia mencapai puncak keberhasilannya dalam momentum Pemilu Presiden Indonesia 2014 yang lalu di mana masing-masing kandidat menggunakan relawan sebagai mesin pemenangan (Purnomo, 2014). Terlepas dari segala kontroversi penggunaan istilah dan proses terbentuknya relawan pendukung calon presiden, social media terbukti memainkan peranan penting dalam memfasilitasi tumbuhnya semangat kerelawanan, yang selanjutnya menjadi kekuatan sosial baru dalam kehidupan

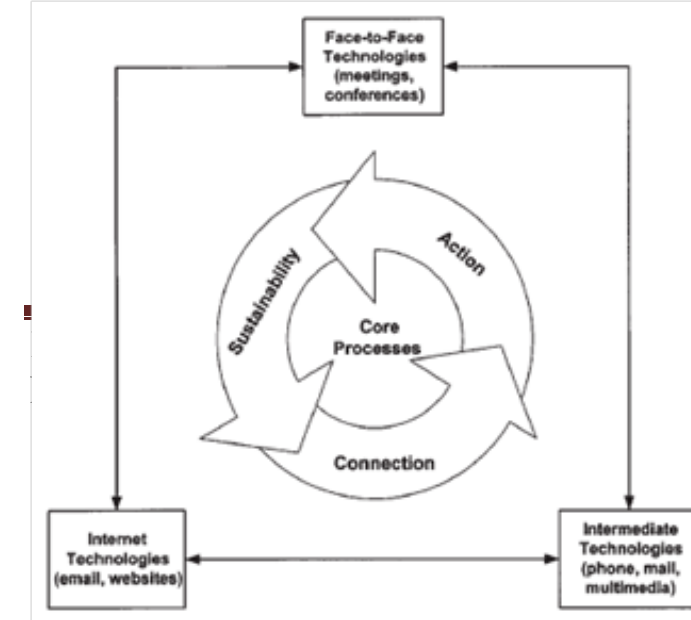

demokrasi Indonesia.

Sumber: C. Lombardo et.al (2002)

Gambar 1. Model Proses dan Penggunaan Teknologi dalam Menunjang Gerakan Sosial Pemuda

Secara umum, penggunaan teknologi komunikasi dan informasi dalam gerakan sosial tidak cukup hanya mengandalkan satu jenis saluran komunikasi atau satu jenis aplikasi social media saja. Mengingat partisipan memiliki perilaku atau kebiasaan menggunakan internet yang berbeda dan bisa berubah sewaktuwaktu. Gerakan sosial memiliki 3 proses inti dalam daur gerakan,

yaitu keterhubungan, aksi, dan keberlanjutan (Lombardo et al., 2002). Pada mulanya adalah adanya hubungan yang memungkinkan terjadinya pertukaran gagasan, kesamaan tujuan, dan terjalinnya komitmen bersama untuk melakukan tindakan atau program. Keberhasilan gerakan sosial tidak berhenti pada terlaksananya sebuah aksi atau program sebagaimana telah direncanakan. Justru tantangan bagi sebuah gerakan sosial adalah keberlanjutan dari program tersebut. Di masing-masing proses membutuhpengelolaan hubungan yang tepat dengan mengkombinasikan antara saluran komunikasi face to face (melalui acara kopi darat, seminar, atau workshop), teknologi intermediate (seperti telepon atau multimedia), dan teknologi internet (email, website, social media). Rangkaian proses dan penggunaan teknologi dalam menunjang gerakan sosial ditunjukan oleh Lombardo et.al (2002) melalui gambar 1. Sebuah model proses inti gerakan sosial dan penggunaan jenis saluran komunikasi yang beragam untuk masing-masing tahapan inti. Gerakan sosial online hanya akan berhasil jika melibatkan, sedikit atau banyak, gerakan offline di dunia nyata. Jika tidak, sebaik apapun gagasan program tersebut hanya akan berhenti sebagai kliktivisme, aktivisme semu dengan memencet tombol di gadget tanpa 
ada perubahan empiris dalam kehidupan nyata.

\section{METODE PENELITIAN}

Metode yang digunakan dalam penelitian ini yaitu kualitatif dengan analisis deskriptif. Metode ini menggunakan wawancara mendalam, dan observasi langsung untuk mendapatkan gambaran dan fakta di lapangan secara langsung. Tipologi studi kasus deskriptif (Yin, 2014) harus menggunakan how (bagaimana) dan why (mengapa) untuk mendapatkan gambaran yang utuh dan mendalam tentang penelitian ini.

Model analisis yang digunakan dalam penelitian ini yaitu menggunakan model analisis studi kasus deskriptif. Dalam pelaksanaannya pendekatan studi kasus yang dapat dikembangkan menggunakan domain ganda sehingga studi kasus ini dapat dihubungkan dengan fenomenafenomena lainnya (Bungin, 2011). Dalam hal ini studi kasus in terdapat dua domain yaitu Pemuda diaspora dalam memaknai pendidikan toleransi dan penggunaan media baru dalam gerakan sosial.

Metode pengumpulan dan analasis data dalam penelitian ini yaitu dilakukan dengan melakukan interview kepada salah satu founder organisasi SabangMerauke dan melakukan penelusuran data-data sekunder yang ada di website, blog dan social media yang digunakan sebagai kanal komunikasi dari SabangMerauke. Data-data tersebut kemudian dianalisis untuk mengembangkan teori yang telah terbangun berdasarkan pengumpulan data di lapangan.

\section{PEMBAHASAN}

\section{Sabang Merauke: Seribu Anak Bangsa Merantau untuk Kembali}

Sebuah pengalaman yang dialami oleh Ayu Kartika Dewi saat tinggal di daerah Papaloang, Halmahera Selatan, Maluku Utara sebagai Pengajar Muda menyisakan kegelisahan yang terus menghantui pikiran meskipun ia sudah selesai bertugas. Saat itu seorang anak kelas 2 SD yang kebetulan beragama Islam mendekat dan memperingatkan $\mathrm{Ayu}$, "Bu $\mathrm{Ayu}$ jangan dekat-dekat orang Kristen. Mereka itu monster. Mereka bisa membahayakan Ibu."("Exchange Program Builds Bridges of Trust," 2014). Kasus ini membuatnya berpikir bagaimana bisa anak yang masih berumur delapan tahun sudah bisa membenci umat agama lainnya. Dalam kesempatan lain selama masa tugasnya sebagai Pengajar Muda tahun 2010-2012, Ayu menemukan kasus yang sama di anak-anak di daerah yang ditinggalinya. Mungkin saja anak kecil itu tidak benarbenar paham kalimat yang mereka ucapkan pada gurunya. Mungkin anak itu bermaksud melindungi gurunya yang kebetulan seagama, atau mungkin itulah prasangka yang diajarkan oleh orang tua dan lingkungan di mana anak itu tumbuh. Tetapi satu hal yang pasti bahwa ekspresi anak kecil itu adalah sebuah kejujuran tentang apa yang sebenarnya terjadi dalam relasi antaragama di masyarakat bawah, terutama masyarakat paska-konflik. Sebagaimana kita tahu, pada tahun 19992003 terjadi konflik berdarah antara umat Islam dengan Kristen di Maluku (Wisudo, 2010). Ekspresi anak kecil tersebut menjadi bukti bahwa sisa trauma dan prasangka terhadap penganut agama lain masih ada dan menurun ke generasi yang belum tentu mengalami peristiwa konflik tersebut.

Berawal dari kegelisahan yang sama ini lah, kemudian memicu tiga anak muda Indonesia untuk membuat ide tentang gerakan sosial SabangMerauke. Program pertukaran ini difokuskan untuk anakanak dari berbagai daerah di Indonesia yang kemudian diberikan bekal pendidikan untuk saling bertoleransi dan menghargai antar sesamanya. Mereka berusaha mengajak anak-anak di Indonesia untuk merayakan perbedaan dan pengertian atas toleransi sehingga anak-anak tersebut dapat merasakan Indonesia seutuhnya (Widiati, 2018).

SabangMerauke merupakan sebuah program tahunan yang memanfaatkan masa liburan sekolah untuk memberikan kesempatan beberapa pelajar dari berbagai daerah yang berasal dari Sabang hingga 
Merauke untuk tinggal dan mengikuti serangkaian kegiatan di Jakarta selama beberapa minggu. Sebagai sebuah gerakan sosial, SabangMerauke bersifat independen yang diinisiasi oleh Ayu Kartika Dewi bersama Aichiro Suryo Prabowo dan Dyah Widiastuti. Nama SabangMerauke merupakan singkatan dari Seribu Anak Bangsa Merantau untuk Kembali. Selain itu SabangMerauke adalah kombinasi dari nama dua wilayah terpinggir dari barat dan timur Indonesia. Nama tersebut sekaligus menjadi gambaran dari program SabangMerauke, yaitu pertukaran siswa dari berbagai wilayah kepulauan di Indonesia. Gerakan ini secara resmi dideklarasikan pada 28 Oktober 2012 bersamaan dengan peringatan hari Sumpah Pemuda di tiga kota yang berbeda yaitu Jakarta, Bogor, dan Tanjung Pinang (Liputan6, 2013).

Sebelum akhirnya memutuskan untuk membuat program SabangMerauke, para pendirinya menemukan ada 2 tantangan besar yang dihadapi bangsa Indonesia. Pertama, perbedaan masih dianggap sebagai sesuatu yang tabu untuk dibicarakan dalam masyarakat. Konflik yang berkaitan dengan suku dan agama tersebut kemudian menyebabkan isu perbedaan menjadi topik yang sensitif. SabangMerauke bermaksud menanamkan semangat Bhinneka Tunggal Ika agar generasi muda dapat mengakui dan menghargai segala perbedaan yang eksis dalam Negara Kesatuan Republik Indonesia sehingga tercipta kehidupan bernegara yang lebih baik dan harmonis.

Kedua, tingkat pembangunan dalam bidang pendidikan di setiap daerah yang berbeda-beda. Ketidakmerataan sarana dan prasarana pendidikan ini menjadi tantangan besar untuk mewujudkan pendidikan yang berkualitas bagi anakanak di seluruh Indonesia. Perbedaan kualitas guru, sarana pendidikan, dan ketersediaan lembaga pendidikan yang lebih tinggi membuat anak-anak di daerah tidak memiliki kesempatan yang sama mengembangkan diri dibandingkan anakanak yang tinggal di perkotaan. Anakanak di daerah yang jauh dari fasilitas pembangunan harus mendapatkan akses pendidikan untuk membuka pikiran dan wawasan agar suatu saat mereka akan menjadi penggerak pembangunan di daerah mereka sendiri ${ }^{1}$.

\section{Menanam Toleransi, Menebar Inspirasi} Sebagai sebuah gerakan baru, SabangMerauke memberikan perhatiannya untuk membangun semangat tentang multikultur dan keanekaragaman di Indonesia. Gerakan sosial ini berniat untuk membuka pemikiran dari anak-anak indonesia khususnya di daerah pelosok tentang pentingnya pendidikan untuk masa depan yang lebih baik. Selain itu mereka juga mengajak anak-anak indonesia untuk belajar bertoleransi dan menanamkan nilai Bhineka Tunggal Ika bagi perdamaian dan membangun kehidupan keanekaragaman yang lebih baik di masa yang akan datang. Karena anak-anak inilah diharapkan untuk kedepannya bisa menjadi pelopor untuk kemajuan dan pembangunan di masingmasing daerah mereka.

Seiring maraknya konflik berbau SARA yang makin meningkat, SabangMerauke menjadi sebuah gerakan sosial yang bertujuan menyebarkan gagasan multikulturalisme. Diinisiasi oleh pemuda, SabangMerauke menargetkan masyarakat umum agar mau terlibat dalam program mereka. Salah satu upaya menyebarkan gagasan, SabangMerauke menggunakan social media. Bahkan pengelola gerakan SabangMerauke menempatkan social media sebagai tulang punggung saluran komunikasi program. Berikut pernyataan dari Meiske Demitria, salah satu pengelola SabangMerauke, dalam wawancara via email.

"Bisa dibilang penggunaan social media adalah back bone kami. Melalui social media, banyak sekali relawan yang bergabung dengan SM. Melalui social media, undangan/ajakan bekerjasama maupun rekomendasi untuk donatur juga

\footnotetext{
${ }^{1}$ Wawancara dilakukan via email tanggal $16 \mathrm{Mei}$ 2014 keapda Meiske Demitria Wahyu yang merupakan salah satu founder SabangMerauke
} 
kami dapatkan. Apalagi social media adalah alat yang sangat dinamis sehingga kami bisa memberikan info-info terbaru setiap saat bagi pendukung $\mathrm{SM}^{2}$.

Aktivis yang berpartisipasi dalam program sebagian besar adalah individu yang concern pada isu pendidikan dan multikulturalisme di Indonesia. Mayoritas dari mereka adalah Pengajar Muda ${ }^{3}$ dan menggunakan relasi mereka dengan beberapa figur publik, instansi pemerintah, dan institusi lain untuk mendukung program SabangMerauke. SabangMerauke juga melibatkan relawan di luar jejaring Pengajar Muda.

Jika dilihat dari sistem manajemen relawan, SabangMerauke berupaya menerapkan sistem yang profesional dengan membagi relawan ke dalam beberapa tim sesuai dengan divisi pekerjaan yang dibutuhkan. Beberapa diantaranya divisi integrated marketing communication, event/kegiatan, manajemen sumber daya manusia, dan manajemen hubungan alumni. Keterlibatan mereka adalah bersifat sukarela. Social media berfungsi sebagai alat komunikasi untuk menyebarkan informasi dan menarik pemuda dari seluruh Indonesia untuk berpartisipasi sebagai relawan SabangMerauke.

Sabang Merauke menyebarkan informasi tentang program mereka melalui akun twitter@SabangMeraukeID untuk menarik masyarakat, khususnya anak muda. Sebagaimana telah disebutkan sebelumnya, target utama SabangMerauke untuk relawan penggerak program adalah anak muda. Oleh karena itu penggunaan social media merupakan langkah tepat untuk menarik perhatian mereka, mengingat mayoritas pengguna social media di Indonesia adalah anak muda. Dalam hal ini, ada dua pola bagaimana social media, khususnya twitter, digunakan dalam program SabangMerauke. Pertama, untuk berbagi

\footnotetext{
${ }^{2}$ Ibid.

${ }^{3}$ Pengajar Muda adalah sebutan bagi peserta program Indonesia Mengajar. Untuk informasi lebih lanjut bisa dilihat di http://indonesiamengajar.org/
}

informasi atau update kegiatan terbaru. Kedua, untuk menyebarkan visi, misi, dan nilai yang diusung SabangMerauke kepada netizen. Hal yang kedua seringkali dilakukan ketika SabangMerauke sedang tidak memiliki rencana kegiatan atau program dalam waktu dekat.

Meskipun social media menjadi alat strategis, namun sebuah gerakan sosial tidak bisa hanya mengandalkan social media saja dalam mengelola sebuah gerakan sosial. Apalagi jika gerakan tersebut melibatkan partisipan yang beragam dari segi usia dan perilaku penggunaan teknologi komunikasi. Dalam kasus SabangMerauke, pendekatan yang sedikit berbeda dilakukan dalam proses seleksi relawan keluarga yang disebut Famili Sabang Merauke. Untuk menarik perhatian keluarga yang bersedia terlibat dalam SabangMerauke, twitter mungkin bukan saluran yang tepat. Mengingat bahwa suami atau istri yang menjadi kepala keluarga bukanlah pengguna social media yang aktif. Bisa dikatakan mereka adalah generasi digital immigrant, bukan digital native. Dalam arti bahwa kepala keluarga yang memutuskan untuk terlibat dalam program ini pernah mengalami beberapa tren teknologi komunikasi mulai dari radio, televisi, telepon rumah, handphone, hingga penggunaan internet baik melalui fixed line maupun mobile. Oleh karena itu pendekatan kepada relawan Famili SabangMerauke perlu disesuaikan dengan latar sejarah penggunaan dan preferensi perangkat teknologi komunikasi yang digunakan. Dalam hal ini, penggunaan teknologi website dan blog menjadi sarana yang lebih sesuai untuk menarik perhatian mereka. Sementara untuk mengelola relasi lebih lanjut, penggunaan teknologi komunikasi intermediate (surat menyurat, telepon, multimedia) dianggap lebih tepat. Mengingat beberapa fasilitas yang harus disediakan oleh relawan Famili SabangMerauke kepada Anak SabangMerauke, yang mana diperlukan negosiasi yang lebih kompleks, panitia merasa perlu melakukan kunjungan ke rumah dan berkomunikasi tatap muka 
dengan calon Famili SabangMerauke. Selain itu komunikasi tatap muka lebih efektif dalam proses membangun kepercayaan antarpihak dibandingkan dengan komunikasi termediasi.

Saat ini, SabangMerauke memiliki website $^{4}$ berfungsi sebagai sumber informasi tentang SabangMerauke, program-program, dan prosedur keikutsertaan. Dengan kata lain, website berisi informasi yang lebih formal. Sementara blog lebih berfungsi sebagai catatan harian dari para relawan yang terlibat dalam batch program sebelumnya. Social media, dalam gerakan SabangMerauke, juga tidak didesain untuk mengelola hubungan dengan alumni. Mengingat SabangMerauke adalah program tahunan, tidak selalu ada informasi terbaru terkait program yang bisa disampaikan melalui website dan social media. Oleh karena itu blog menjadi sarana yang disediakan untuk berbagi pengalaman atau cerita paskaprogram. Melalui blog, semua partisipan bisa menulis pengalaman personal, kejadian mengesankan, atau refleksi yang mereka dapatkan selama mengikuti atau setelah program berlangsung. Dari cerita tersebut, SabangMerauke berharap agar netizen secara umum bisa ikut menikmati, merasakan atau mengambil pelajaran tentang nilai-nilai pendidikan, semangat toleransi, dan kebangsaan yang bisa mereka terapkan dalam kehidupan seharihari.

Sebagai gerakan yang masih terbilang baru, saat ini SabangMerauke masih berada pada tahap pembangunan kesadaran (awareness building) oleh masyarakat. Sedangkan brand awareness ke terbagi ke dalam empat tahap (Aaker, 1991). Tahap pertama adalah ketika orang-orang masih tidak sadar akan keberadaan brand tersebut. Tahap kedua adalah brand recognition, yaitu kondisi ketika orang-orang mulai dapat mengenali brand tersebut. Tahap ketiga adalah brand

${ }^{4}$ SabangMerauke website URL is $\mathrm{http}: / /$ sabangmerauke.id/ recall, yang terjadi ketika orang-orang sanggup mengingat brand tersebut pada saat mereka mengalami beberapa kejadian yang berkaitan dengan brand. Yang terakhir adalah level top of mind, yaitu ketika orang-orang dapat menempatkan brand tersebut dalam ingatan mereka yang paling dalam. Pada dasarnya, sebagai pionir dari gerakan social media yang berkonsentrasi pada isu toleransi dan multikulturalisme, SabangMerauke memiliki kesempatan untuk mencapai posisi top of mind.

Dalam usahanya untuk membangun kesadaran pada cakupan masyarakat yang lebih luas, SabangMerauke menggunakan publisitas seperti social media, buzzer, dan gerakan-gerakan lainnya sebagai pihak pendukung. Cakupan publikasi SabangMerauke tidak terbatas hanya pada media nasional saja, melainkan juga media internasional. Pada tahun 2013, SabangMerauke berkesempatan untuk diliput oleh Al Jazeera English dan Strait Times. Terlebih lagi, SabangMerauke juga memiliki kesempatan untuk diliput oleh beberapa media nasional seperti Jakarta Globe, Media Indonesia, Hardrock FM, dan Trax FM. Melalui media massa, informasi tentang SabangMerauke dapat menjangkau masyarakat yang lebih luas yang belum dapat tersentuh oleh akses internet.

Di samping menerima dukungan dari media nasional dan internasional, SabangMerauke juga menerima dukungan dari gerakan-gerakan sosial yang lain, seperti@indorelawan,@NEGMUS, @jadipm,@selasarcom, dan Gerakan Indonesia Berkibar. Baru-baru ini, SabangMerauke juga memeroleh kesempatan untuk melakukan "twitalk" atau live talk show melalui Twitter bersama@IPAConvex dan Gerakan Indonesia Berkibar. Untuk soal mengorganisir talk show, tim IMC yang sehari-harinya bertanggungjawab untuk menangani dan mengelola akun-akun social media SabangMerauke akan meminta perwakilan tim manajemen untuk menjadi informan. Orang yang kerap menjadi informan adalah para 
pendiri, direktur pelaksana, atau tim perancang formula SabangMerauke. Terkadang, SabangMerauke juga mengajak para partisipan dari batch pertama untuk bergabung dalam wawancara.

Kolaborasi antara SabangMerauke dan gerakan-gerakan lainnya tidak secara formal direncakan dalam skema rancangan kerja kemitraan. Pada umumnya, SabangMerauke meminta pada partner (gerakan lainnya) untuk melakukan retweet dan share informasiinformasi pada jaringan mereka sendiri. Karena tidak adanya rancangan kerja kemitraan yang formal, maka dukungan yang saling timbal balik menjadi satusatunya keuntungan yang bisa ditawarkan. Kolaborasi antara SabangMerauke dan gerakan-gerakan lainnya dapat terwujud karena -meskipun setiap gerakan memiliki fokus dan isu pada ranah yang berbeda- pada dasarnya mereka memiliki semangat dan tujuan yang sama.

Para penggerak yang berpartisipasi untuk mendukung gerakan SabangMerauke ini merupakan para generasi muda yang perhatian dengan isu-isu multikulturalisme dan pendidikan. Sebagian besar dari mereka merupakan pengajar muda dari gerakan Indonesia Mengajar $^{5}$ yang kemudian menggunakan jaringannya untuk membangun relasi ke para tokoh, pemerintah dan Institusiinstitusi untuk mendukung gerakan SabangMerauke ini. Selain itu relawanrelawan lainnya yang bukan berasal dari pengajar muda juga turut mendukung gerakan ini. Selain itu mereka juga membuat management organisasi secara profesional agar gerakan ini dapat terus berlangsung.

Di sisi lain, kaum muda adalah generasi paling menjanjikan di Indonesia. Mereka tidak memiliki pengalaman masa lalu

${ }^{5}$ Indonesia Mengajar merupakan sebuah gerakan sosial yang diinisiasi oleh Anies Baswedan, Rektor Universitas Paramadina. Program ini di bentuk untuk mendorong anak muda indonesia untuk mengajar anak-anak di daerah pelosok Indonesia. Untuk informasi lebih lanjut bisa dilihat di $\mathrm{http}$ ://indonesiamengajar.org/ traumatis terkait konflik multikulturalisme yang terjadi pada masa Orde Baru. Mereka adalah generasi yang secara aktif merespon isu-isu seputar multikulturalisme, nasionalisme, dan kemanusiaan. Keberadaan media sosial pun telah menjadi platform yang ideal bagi para kaum muda untuk dapat berpartisipasi secara aktif dalam membawa perubahan pada masyarakat melalui gerakan sosial.

Table 1. Analisis Jenis Saluran dan Teknologi Komunikasi yang Digunakan dalam Gerakan SabangMerauke

\begin{tabular}{|c|c|c|}
\hline $\begin{array}{c}\text { Saluran } \\
\text { Komunikasi }\end{array}$ & Fungsi & $\begin{array}{c}\text { Pihak yang } \\
\text { berkepentinga } \\
n \\
\end{array}$ \\
\hline $\begin{array}{l}\text { Tatap muka } \\
\text { (komunikasi } \\
\text { interpersonal. } \\
\text { seminar, } \\
\text { workshop) }\end{array}$ & $\begin{array}{l}\text { Membangun } \\
\text { kepercayaan } \\
\text { antarpihak } \\
\text { Pendidikan } \\
\text { dan } \\
\text { peningkatan } \\
\text { kesadaran } \\
\text { Pelatihan dan } \\
\text { membangun } \\
\text { kapasitas } \\
\text { (skill } \\
\text { building) }\end{array}$ & $\begin{array}{l}\text { Relawan } \\
\text { (meliputi } \\
\text { Kakak } \\
\text { SabangMerauk } \\
\text { e (SM), Famili } \\
\text { SM, dan } \\
\text { donatur } \\
\text { program) } \\
\text { Relawan } \\
\text { (Kakak SM, tim } \\
\text { pelaksana), } \\
\text { Relawan } \\
\text { (Kakak SM, tim } \\
\text { pelaksana) }\end{array}$ \\
\hline $\begin{array}{l}\text { Email } \\
\text { (personal, } \\
\text { milis) }\end{array}$ & $\begin{array}{l}\text { Promosi } \\
\text { program } \\
\text { Koordinasi } \\
\text { pelaksanaan } \\
\text { Mengelola } \\
\text { hubungan } \\
\text { Diseminasi } \\
\text { informasi }\end{array}$ & $\begin{array}{l}\text { Calon donatur } \\
\text { Relawan } \\
\text { Pengelola } \\
\text { program }\end{array}$ \\
\hline Telepon & $\begin{array}{l}\text { Koordinasi } \\
\text { program }\end{array}$ & $\begin{array}{l}\text { Relawan, } \\
\text { Donatur, ASM, } \\
\text { Keluarga ASM }\end{array}$ \\
\hline \multicolumn{3}{|l|}{ Internet } \\
\hline Website & $\begin{array}{l}\text { Informasi } \\
\text { resmi tentang } \\
\text { visi misi, dan } \\
\text { nilai gerakan } \\
\text { Pengumuman } \\
\text { resmi tentang } \\
\text { tata cara } \\
\text { keikutsertaan } \\
\text { dan tahapan } \\
\text { program }\end{array}$ & $\begin{array}{l}\text { Pihak-pihak } \\
\text { baik individu } \\
\text { maupun } \\
\text { lembaga yang } \\
\text { berpotensi } \\
\text { terlibat }\end{array}$ \\
\hline Twitter & $\begin{array}{l}\text { Update } \\
\text { informasi } \\
\text { singkat }\end{array}$ & $\begin{array}{l}\text { Relawan, } \\
\text { terutama Kakak } \\
\text { SM dan }\end{array}$ \\
\hline
\end{tabular}

ISSN: 2355-0287, e-ISSN: 2549-3299 


\begin{tabular}{|c|c|c|}
\hline & $\begin{array}{l}\text { selama } \\
\text { kegiatan } \\
\text { berlangsung } \\
\text { sesuai } \\
\text { dengan } \\
\text { tahapan } \\
\text { program } \\
\text { Promosi } \\
\text { program } \\
\text { Rekruitmen } \\
\text { terbuka untuk } \\
\text { relawan } \\
\text { Pengumuman } \\
\text { hasil seleksi }\end{array}$ & $\begin{array}{l}\text { pengelola } \\
\text { kegiatan }\end{array}$ \\
\hline Facebook & $\begin{array}{l}\text { Update } \\
\text { informasi } \\
\text { atau gambar } \\
\text { selama } \\
\text { kegiatan } \\
\text { berlangsung } \\
\end{array}$ & $\begin{array}{l}\text { Semua } \\
\text { stakeholder dan } \\
\text { Netizen secara } \\
\text { umum }\end{array}$ \\
\hline Instagram & $\begin{array}{l}\text { Update } \\
\text { Informasi } \\
\text { Visual terkait } \\
\text { kegiatan, } \\
\text { Promosi } \\
\text { Program } \\
\text { serta Ucapan } \\
\text { terimakasih } \\
\text { kepada para } \\
\text { donatur dan } \\
\text { pendukung } \\
\text { acara } \\
\end{array}$ & $\begin{array}{l}\text { Semua } \\
\text { stakeholder dan } \\
\text { Netizen secara } \\
\text { umum }\end{array}$ \\
\hline $\begin{array}{l}\text { Media massa } \\
\text { cetak/ online }\end{array}$ & $\begin{array}{l}\text { Publisitas } \\
\text { Meningkatka } \\
\text { n kesadaran } \\
\text { publik terkait } \\
\text { isu dan } \\
\text { program }\end{array}$ & $\begin{array}{l}\text { Publik secara } \\
\text { umum } \\
\text { Calon } \\
\text { partisipan } \\
\text { Lembaga sosial } \\
\text { dan lembaga } \\
\text { pemerintah }\end{array}$ \\
\hline
\end{tabular}

\section{PENUTUP}

Indonesia sebagai sebuah negara yang mempunyai beragam adat, budaya dan agama menjadikan masyarakatnya menjadi sangat multukultur yang sangat mudah terjadi konflik. Gagasan pendidikan multikulturalisme yang menjadi nilai dari gerakan SabangMerauke mengajarkan toleransi menjadi sebuah aktifitas yang harus dialami dan dirasakan oleh pesertanya. Diaspora lokal yang dialami oleh para pendiri SabangMerauke terhadap kehidupan multibudaya di Indonesia ini menjadikan mereka lebih toleran terhadap masyarakat di sekitarnya. Diaspora yang dilakukan oleh SabangMerauke untuk membangun toleransi ini juga sesuai dengan konsep peran diaspora yang dapatt membantu pembangunan nasional sesuai dengan pemikiran (Busumtwi-Sam \& Anderson, 2010). SabangMerauke menggunakan komunitsnya (Community), memanfaatkan keunggulan geografis (Trans-Locality) dan bekal jaringannya (Network) dalam melaksanakan kegiatannya.

Beragam saluran di media baru pun juga digunakan untuk menjalin hubungan antara SabangMerauke dengan stakeholdernya. Hal ini dilakukannya untuk menjaga sustainability (kesinambungan) gerakan sosial sehingga tidak hanya berakhir menjadi aktivisme semu melalui media baru. Seperti prinsip dari Lombardo et al. (2002) yaitu gerakan sosial online yang berkesinambungan tidak hanya mengandalkan aktivitas di dunia maya saja akan tetapi gerakan tersebut harus membumi sehingga diperlukan adanya aktifitas-aktifitas offline yang bisa saling mendukung persebaran ilmu (knowledge-sharing) antar stakeholdernya.

\section{REFERENSI}

Aaker, D. A. (1991). Managing Brand Equity. New York: Free Press.

Aday, S., Sides, J., Kelly, J., Zuckerman, E., Borrowman, B., Guaglianone, J., ... Whitlark, R. (2010). Blogs and bullets: New media in contentious politics. In Peaceworks (Vol. 65). Washington DC.

APJII. (2015). Profil Pengguna Internet Indonesia 2014 (Pertama; U. Puskakom, Ed.). Jakarta: APJII.

APJII. (2018). Penetrasi dan Perilaku Pengguna Internet Indonesia 2017. In APJII. Jakarta.

Bungin, B. (2011). Penelitian Kualitatif: Komunikasi, Ekonomi, Kebijakan Publik, Dan Ilmu Sosial Lainnya. In Kencana. https://doi.org/10.1002/jcc.21776

Busumtwi-Sam, J., \& Anderson, R. (2010). 'Trans-Local' Diaspora and Development: A Concept and Research Note. Retrieved from http://www.sfu.ca/diasporas/pdf/App endix_120.pdf 
Clark, E. (2012). Social Movement \& Social Media : A qualitative study of Occupy Wall Street. Södertörn University, School of Culture and Communication.

Cohen, R. (2008). Global diasporas: An introduction, second edition. In Global Diasporas: An Introduction, Second Edition. https://doi.org/10.4324/9780203928 943

Exchange Program Builds Bridges of Trust. (2014). Retrieved from The Jakarta Post website:

https://www.thejakartapost.com/new s/2014/06/28/exchange-programbuilds-bridges-trust.html

Lim, M. (2013). Many Clicks but Little Sticks: Social Media Activism in Indonesia. Journal of Contemporary Asia.

https://doi.org/10.1080/00472336.20 13.769386

Liputan6. (2013). SabangMerauke Sebarkan Virus Toleransi di Indonesia. Retrieved from Liputan6 website:

https://www.liputan6.com/citizen6/r ead/609621/sabangmeraukesebarkan-virus-toleransi-diindonesia

Lombardo, C., Zakus, D., \& Skinner, H. (2002). Youth social action: Building a global latticework through information and communication technologies. Health Promotion International, 17(4), 363-371. https://doi.org/10.1093/heapro/17.4. 363

MRI. (2019). Beranda.

Nugroho, Y., \& Syarief, S. S. (2012). Beyond Click-Activism? Social Media and Political Processes in Contemporary Indonesia (First Ed.). Berlin: Fesmedia Asia.

Purnomo, W. A. (2014). LSI: Relawan Kunci Kemenangan Jokowi. Retrieved from Tempo.co website: https://pemilu.tempo.co/read/592012 /lsi-relawan-kunci-kemenanganjokowi/full\&view=ok
Sharpe, J. (2014). Meet Indonesia's middle class. Retrieved September 17, 2014, from LOWY INSTITUTE: The Interpreter website: https://www.lowyinstitute.org/theinterpreter/meet-indonesias-middleclass

Speevak-Sladowski, P., Hientz, M., \& MacKenzie, R. (2013).

Volunteering: A Catalyst for Citizen Engagement, Social Inclusion, and Resilient Communities. The Philanthropist, 25(1), 37-44. Retrieved from https://hephilanthropist.ca/2013/02/ volunteering-a-catalyst-for-citizenengagement-social-inclusion-andresilient-communities/

Wahyu, Meiske D. (2014, May). Email Interview

Widiati, S. (2018). SabangMerauke Aims to Foster an Atmosphere of Tolerance.

Wisudo, B. P. (2010). Bertaruh Nyawa, Merajut Damai (Pertama). Jakarta: Yayasan Tifa.

Yin, R. K. (2014). Case study research: Design and methods (5th ed.). In Thousand Oaks, CA: SAGE Publications.

\section{BIODATA PENULIS}

Syaifa Tania mendapatkan gelar sarjana dan pasca sarjananya di Departemen Ilmu Komunikasi Fakultas Ilmu Sosial dan Ilmu Politik Universitas Gadjah Mada. Saat ini aktif sebagai staf pengajar tetap di Departemen Ilmu Komunikasi FISIPOL UGM. Fokus penelitian yang sedang dikembangkan yaitu media digital dan komunikasi pemasaran.

Massageng Widagdhaprasana mendapatkan gelar sarjana ilmu politik di bidang komunikasi dari Fakultas Ilmu Sosial dan Ilmu Politik Universitas Gadjah Mada di tahun 2010. Pada tahun 2017, melanjutkan pendidikannya di program master of marketing communications di University of Melbourne, Australia. Saat ini aktif sebagai staff pengajar kontrak di Departemen Ilmu Komunikasi Fisipol 
UGM dan aktif sebagai tim taskforce pendirian International Undergraduate Program in Communication di Departemen Ilmu Komunikasi, FISIPOL, UGM.

\section{Mashita Phitaloka Fandia}

Purwaningtyas mendapatkan gelar sarjana dari Departemen Ilmu Komunikasi Fisipol UGM dan gelar pasca sarjana di sekolah Pasca Sarjana Universitas Gajah Mada di program master kajian Media dan Budaya. Saat ini aktif sebagai staff pengajar tetap Departemen Ilmu Komunikasi FISIPOL UGM dan fokus penelitiannya di bidang digital media dan culturalstudies.

Maulin Niam saat ini aktif sebagai staff peneliti di Departemen Ilmu Komunikasi FISIPOL UGM. Menempuh Pendidikan S1 di Departemen Ilmu Komunikasi FISIPOL UGM. Fokus penelitiannya berada di area Pendidikan, masyarakat digital dan kajian budaya. 